\title{
Sustainable Development and Sustainability in Engineering Education in Nigeria
}

\author{
Igogbe Regina Onyilo, Mahyuddin Bin Arsat, Terungwa Stephen Akor, Adibah Abdul Latif, \\ Nor Fadilah Mohd Amin
}

\begin{abstract}
Following the United Nation's pronouncement of 2005-2014 as the Decade for Education for Sustainable Development (DESD), education and particularly Higher Education was earmarked as the most convenient and appropriate vehicle for advancing training and awareness for sustainability and sustainable development. This study reviewed articles to investigate the level of awareness about ESD among engineering stakeholders in Nigeria and also to investigate the various approaches that could be used to integrate Sustainability in Engineering Education curriculum in Nigeria. The study employed a systematic review on Sustainable Development and Sustainability in Engineering Education in Nigeria. Articles on Sustainability Education and Sustainability in Engineering were analyzed using inductive content analysis. The review showed that, there is lack of awareness about ESD even among engineering stakeholders; and approaches such as: modular/ Bolt-in, Project Based Learning (PBL), Integrative Learning, Problem Project Based Learning (PPBL), amongst others were found out to be used by scholars in other parts of the world for incorporating sustainability in their Engineering Education programs. It could be a Stand-alone or an Integrated course. The researcher therefore suggests the use of any of these approaches to institutions and faculties planning to integrate sustainability in their programs. This study recommends that; for sustainable education to yield a meaningful result, Government should create awareness about the need for sustainability in the country. This can be done through Sustainability Education intervention and implementation of Sustainability Policies.
\end{abstract}

Index Terms: Education for Sustainable Development in Nigeria, Sustainability Education, Sustainability Development in Engineering.

\section{INTRODUCTION}

As the world currently faces energy, environmental and economic crisis as a result of unhealthy human practices on natural resources and the environment, the demand for more efficient buildings, homes, transportation, consumer products and alternative renewable energy that will positively affect the society has remained the yearnings of many nations. Having seen this, the United Nation (UN) constituted 2005-2014 as the Decade for Education for Sustainable Development (DESD). The Agenda 21 of the UNDESD emphasizes the link that must be constructed between academia as well as the needs of the community

Revised Manuscript Received on April 19, 2019.

Igogbe Regina Onyilo, Department of Technical and Engineering Education, Universiti Teknologi Malaysia, Johor Bahru, Malaysia.

Mahyuddin Bin Arsat, Department of Technical and Engineering Education, Universiti Teknologi Malaysia, Johor Bahru, Malaysia.

Terungwa Stephen Akor, Department of Technical and Engineering Education, Universiti Teknologi Malaysia, Johor Bahru, Malaysia.

Adibah Abdul Latif, Department of Educational Foundations and Social Sciences, Universiti Teknologi Malaysia, Johor Bahru, Malaysia.

Nor Fadila Mohd Amin, Department of Technical and Engineering Education, Universiti Teknologi Malaysia, Johor Bahru, Malaysia and also to enact sustainability in higher education in order to positively affect the society as well as biosphere [1]. Four main objectives were identified by UNESCO that will do this plan

of which the second speaks straight to education, which is "Rethinking as well as Revisiting education from nursery school to university to include a clear aim of future and current societies on the development of knowledge, skills, attitudes and values in connection with sustainability". This implies that; the objectives and contents of existing curricula from Nursery education to University education should be reviewed and developed to integrate the interdisciplinary understanding of social, economic and environmental sustainability; and also to recommend and make mandatory the methods of teaching, learning and assessment of sustainability programmes. In other to achieve this great feat, education and higher education in particular was earmarked by united nations as the most convenient and appropriate avenue for advancing this training and creation of awareness about sustainability.

Engineering Education is being taught in Nigeria at University level as well as Polytechnics level. The National Universities Commission (NUC) is actually the government umbrella group which oversees the administration of Higher Education in Nigeria. NUC being the administrative body of Universities listed 152 universities as accredited degree granting institution in the site of its report as at 2017[2]. In addition to Universities, National Board for Technical Education (NBTE), the federal government body which oversees Polytechnics in Nigeria, recognized 107 polytechnics in Nigeria as at 2017. Engineering Education in Nigeria based on [3], is actually acquired over a period of 5 years in Universities and 2 years in Polytechnics. In the first and second year of studies, engineering education learners are usually taught Chemical and Physical Science subjects that is ordinarily accompanied by one or perhaps two Social Science subjects like use of English. Learners are progressively subjected to the core of the chosen disciplines of theirs within the three years and inside the 3years research of core engineering, students are actually required to go through a mandatory Industrial Work Experience Scheme serving as an avenue to come across the actual world of work of the engineering programme. Engineering students then undertake a research project either collectively or individually under the supervision of an academic in the last session of the programme of theirs. A Bachelor of Engineering is actually given to the engineering graduates

Published By: 
upon effective completion of the programme.

Various research findings have revealed that, lack of adoption and implementation of sustainability policies, strategies and programmes in the industries and educational curriculum arethe major factors responsible for poor infrastructural development, ecological and economic challenges looming in Nigeria today [4] [5] [6]. Having being recognized as the lifeblood of socioeconomic progress in any nation, engineering is seen as the solution to the challenges of sustainability. Engineering community all over the world have invented sustainable engineering as a concept that will help them leave the conventional Engineering practice. However, [7] are concerned that, the question regarding the extent to which the sustainability worldview has been embraced by the Nigerian Engineering community remains unanswered. This review is

Table I. Results of Retrieved Articles according to keyword against the database

\section{Sustainable Education}

Research Gate

Science Direct

119

561

12

692

\section{Sustainability \\ Development Engineering 78}

294

8

380

\section{Education for sustai
Development in Nigeria}

125

64

4

193

\section{Total}

1265 actually an effort to respond to the question about the knowledge of sustainability among the members of the Nigerian Engineering community and how can sustainability education be incorporated into Engineering Education Programme in Nigeria.

Since the inception of the idea about sustainability, curriculum developers and course designers have been faced with the tough challenge of transforming higher education curriculum at large, and engineering education in particular, to embrace sustainable development. It was also established that embedding sustainability into education system plays a vital role towards the realization of sustainable development goals. However, in many under-developed countries, especially in Sub-Sahara Africa(SSA), the issue of integrating sustainability into curricula is still far with the system of education. Despite this challenges and higher demand on sustainable development (SD) in tertiary levels, many universities worldwide according to [8] had included $\mathrm{SD}$ in their programmes. For instance, Japan's Action Plan in 2006 formally ushered in the establishment of undergraduate programmes that promotes Education for Sustainable Development (ESD) as part of its efforts to transform higher education in Japanese universities.

In Malaysia, ESD in higher education curriculum started in 1998, and from 2005, implementation of ESD was witnessed in various universities in Malaysia. As a matter of fact, Universiti Teknologi Malaysia, introduced "Plant Design" as an integrated sustainable course in Chemical Engineering programme. A lot of models for the approaches for integrating sustainability were used and/or proposed by different sustainability educators and researchers in higher education across the globe. In essence therefore, a systematic study is needed to explore various approaches of sustainability integration in Nigerian higher education, particularly, in Engineering Education programme.

\section{RESEARCH QUESTIONS}

This study was intended to investigate the knowledge about sustainability among engineering stakeholders and

also examine the different approaches of integrating sustainability into Engineering Education in Nigeria. The study sought to answer the following questions:

1. What is the level of awareness of Sustainable Development among Engineering community in Nigeria?

2. What are the approaches of integrating sustainability in Engineering Education Curricula in Nigeria?

\section{METHODOLOGY}

This study systematically reviewed the existing literature to extract the relevant studies to be considered. In accordance with the title, the study seeks to determine the Sustainable Development awareness and approaches of integration of sustainability into engineering education in Nigeria. Some databases namely: Science Direct, Research gate and other literature sources were explored. The following keywords were used; sustainability education; sustainability development in Engineering and Education for sustainable Development in Nigeria. A large number of materials was arrived at and in order to reduce the number of articles to a manageable size, the following criteria was used:

i. The documents were restricted to articles between 2014 and 2019.

ii. Search was limited to the title of the study.

With no further limit set on the literature search, the search produced the following articles in table 1 .

As shown in table 1 above, the use of the keywords: Sustainable Education; Sustainable Development in Engineering; and Education for Sustainable development in Nigeria across the explored databases produced 692, 380 and 193 results respectively.

After the duplicates were removed by comparing the titles based on the keywords, the total number was reduced to 482. The 482 articles were further reduced to 102 by 
removing the works that are not directly related to engineering. Further reduction to cover only works done in engineering education in Nigeria brought the total number of articles to 34. At last, only 23 articles were considered for the review after checking the ones that could be retrieved using various retrieval methods. The final sampled articles were analysed qualitatively using an inductive analysis and summarized as shown in the Table 1 above.

\section{FINDINGS}

Awareness on Sustainable Development by Engineering Community in Nigeria.
Research carried out by [3] on Engineering Education and Sustainability in Nigeria using the analysis of BMAS document (Benchmark Minimum Academic Stanadard is a document that sets out standards of running 'university' engineering programmes in Nigeria) shows that, sustainability merely forms $2 \%$ of the entire document and sustainability topics have not received much attention in Nigeria. Also in 2019, [7] conducted yet another research on, Assessment of Sustainability literacy among Engineering Community. This revealed unsatisfactory literacy

Table II. Awareness on Sustainable Development among Engineering Community.

\begin{tabular}{|c|c|c|c|}
\hline Citation & Journal & Type of study & Findings \\
\hline $\begin{array}{c}\text { Akeel, Bell \& Mitchell } \\
\text { (2019) }\end{array}$ & $\begin{array}{c}\text { Journal of cleaner } \\
\text { production, Vol 212; pg } \\
\text { 666-676 }\end{array}$ & Survey & Low awareness of UNDESD. \\
\hline $\begin{array}{c}\text { Nwojuola \& Alant (2018) } \\
\text { penewable Energy, Vol 139, } \\
\text { pg 1366-1374 }\end{array}$ & $\begin{array}{c}\text { Mixed-method } \\
\text { Lenergy tech. \& lack of awareness of } \\
\text { SD }\end{array}$ \\
\hline $\begin{array}{c}\text { Nwokocha, Okoro \& Usoh } \\
\text { Fayom \& Okolie (2019) }\end{array}$ & $\begin{array}{c}\text { Renewable Energy, Vol } \\
\text { 116(A), pg 176-182 }\end{array}$ & Survey & $\begin{array}{c}\text { Lack of awareness \& information; } \\
\text { policy implementation. }\end{array}$ \\
\hline $\begin{array}{c}\text { Oluseyi \& Olusola (2017) } \\
\text { prergy Procedia, Vol. 157, }\end{array}$ & $\begin{array}{c}\text { Journal of sustainable } \\
\text { Architecture and civil } \\
\text { Engineering. 4: 23-28 }\end{array}$ & Review & $\begin{array}{c}\text { Lack of funding support; poor } \\
\text { organisation; fraud \& absence of } \\
\text { training for knowledge gain. }\end{array}$ \\
\hline Akeel, Bell \& Mitchell & $\begin{array}{c}\text { SEFI Conference Procedia, } \\
\text { (2017) }\end{array}$ & $\begin{array}{c}\text { Environmental and Sustainability } \\
\text { level in schools is below average. } \\
\text { No course offered on Sustainability } \\
\text { in their programme. }\end{array}$ \\
\hline
\end{tabular}

Table III. Approaches of integrating sustainability in Engineering Education curriculum in Nigeria

\begin{tabular}{|c|c|c|c|}
\hline Citation & Journal & Design & Approaches \\
\hline $\begin{array}{l}\text { Shing, Mohamad \& } \\
\text { Raman (2016) }\end{array}$ & $\begin{array}{l}\text { Int'l Journal of Engr. Edu. } \\
\text { Vol.2,(6) }\end{array}$ & Survey & Bolt-on approach \\
\hline $\begin{array}{c}\text { Iyer-Raniga \& Andamon } \\
\text { (2016) }\end{array}$ & $\begin{array}{c}\text { Int'l Journal of } \\
\text { Sustainability in Higher } \\
\text { Edu., Vol. 17(1) }\end{array}$ & Conceptual / view point & Outcome/ practice-led approach \\
\hline $\begin{array}{l}\text { Halbe, Adamwoski \& } \\
\text { Paul-Wostl. (2015) }\end{array}$ & $\begin{array}{c}\text { Journal of Cleaner } \\
\text { production, Vol. } 106\end{array}$ & Case study & Integrative learning approach \\
\hline Guerra, (2017) & $\begin{array}{c}\text { Int'l Journal of } \\
\text { sustainability in Higher } \\
\text { Education, Vol.18, (3) }\end{array}$ & $\begin{array}{c}\text { Qualitative Research } \\
\text { Design }\end{array}$ & Problem Based Learning \\
\hline $\begin{array}{c}\text { Husgafvel, Martikka, } \\
\text { Egas Ribiero \& Dahl } \\
(2017)\end{array}$ & $\begin{array}{l}\text { Int'l Journal of Higher } \\
\text { Education, Vol. 16, } 2\end{array}$ & Stand-Alone course & Modular approach \\
\hline $\begin{array}{c}\text { McConville, Rauch, } \\
\text { Helgegren \& Kain (2017) }\end{array}$ & $\begin{array}{c}\text { Int'l Journal of } \\
\text { Sustainability in Higher } \\
\text { Edu., Vol. 18, (4) }\end{array}$ & $\begin{array}{l}\text { Survey/ course } \\
\text { evaluation }\end{array}$ & Role-playing games approach \\
\hline $\begin{array}{l}\text { Rhee, Oyamot, et al } \\
\text { (2014) }\end{array}$ & $\begin{array}{c}\text { Advancies in Engr, Edu., } \\
\text { Vol. } 4(2)\end{array}$ & $\begin{array}{l}\text { Mixed- method } \\
\text { Research }\end{array}$ & $\begin{array}{c}\text { Multidiscilinary Project- Based } \\
\text { instructive approach }\end{array}$ \\
\hline
\end{tabular}


performance of the Nigerian Engineering stakeholders on all three sustainability literacy criteria. The result shows that majority of the students $(81 \%)$, educators $(67 \%)$ and practitioners $(64 \%)$ were unaware of the ESD.

A study by [9] on Evaluating Building Sustainability Literacy level in Nigeria Architectural Education in southwest Nigeria; is also in accord with that of Akeel et al above. The survey revealed that, $78.2 \%$ of the architecture students opined that they understand building sustainability but failed to justify this position when probed further. $13.5 \%$ of the respondents insists that environmental and sustainability literacy level in their school is much below average. Infact, $27.6 \%$ admitted that they have never been offered any building sustainability courses. Worst still, a fair percentage of the respondents $(30.7 \%)$ are not sure whether

their course contents are in anyway tailored towards sustainability. In another development, the qualitative survey

conducted by [10] on Photovoltaics in Nigeria Awareness, Attitudes and expected benefits across regions in Nigeria with its goals tailored to deal with increase in need for energy; growing problems from the environment and also the constraints of typical sources of energy, have proven that the participants have a low level information of unlimited energy systems as well as vast majority of the participants weren't conscious of Sustainable Development. This is an indicative of the fact that; sustainability development in Nigeria is far from meeting up with the United Nation ESD declaration.

what are the Strategies for Sustainability integration in Higher Education curriculum?

Table 3 above analysed the approaches that were used by various researchers to integrate sustainability into curricula. There include; modular approach, [10] Problem and Project Based Learning, [11] Transdisciplinary approach, [12]Multidisciplinary Project Based instructive learning, [13]Role-playing/ games approach, Problem Based Learning,[14] Interactive Learning approach, [15]Bolt-on approach and Outcome/ practice-led approach.

Table 3 further discloses that the leading and predominant approaches used by scholars are the Modular Approach and Problem Based Project Learning PPBL. Therefore, these two approaches Modular Approach and Problem Project Based Learning are the leading and predominant approaches based on this analysis.

\section{IMPORTANT REMARKS}

Education and particularly Higher education was identified by the United Nations as the most convenient and appropriate vehicle for advancing training and awareness for sustainability development. one of the aims of Sustainability Education is to induce in individuals the cognitive orientation needed for an increasingly complex and unpredictable world. It was also established that embedding sustainability into education system plays a vital role towards the realization of sustainable development goals. According to [3], Nigeria has engineered many infrastructure, such as crude oil refineries, Ajaokuta Steel plant, Roads, Railways, Mining and many residential and office buildings. Nevertheless, Nigeria engineering
Education has not been assessed for its sustainability content. To this effect, the researcher attempted to find out the level of the awareness about the ESD among engineering community and to determine the approaches to employ to integrate sustainability in the curricula of engineering education in Nigeria.

[16] in their study on sustainability development and energy education in Nigeria reveals that, the participants have demonstrated a low-level knowledge about renewable energy technologies and lack of awareness about sustainable development. The result of the study indicates that, the nation's science and technology policies needs to broaden its education curriculum to incorporate ideas relating to renewable energy and sustainable livelihood. To further emphasize the recent survey to assess the sustainability literacy in the Nigerian engineering community by [7] which revealed an unsatisfactory performance of the Nigerian Engineering stakeholders on all three sustainability literacy criteria and the result indicating that, the majority of the students $(81 \%)$, educators $(67 \%)$, and practitioners $(64 \%)$ were unaware of the UNDESD. The paper therefore highlights the need to improve the knowledge about sustainability among Nigerian engineering community, possibly through a sustainability education intervention. A possible intervention could be the substitution of common engineering course with sustainable engineering modules. Alternatively, inserting a course titled "Introduction to Sustainable Engineering" which could be made a core requirement from the third year because the third year marks the beginning of core courses for students of all engineering discipline.

A possible way forward was also proffered in the study by[9], $90.1 \%$ of the respondents recommends that, more Environmental and Building Sustainability courses be introduced into architectural curriculum in Nigeria and also regulatory bodies such as NUC and NBTE that formulate and regulate the curriculum of universities and polytechnics should design courses in their programmes aimed at exposing the relevant architecture experts and consultants to current trends in sustainability principles, theories and practices.

Various approaches of integrating SD into the curriculum was proposed by many scholars. [17]in their review of literature on integrating sustainability in Engineering curriculum, reffered to Kemp (2006) submission on SD integration. Kemp is of the position that the concept of sustainable development can be attached to normal disciplinary courses or a new SD elementary course can be designed. Alternatively, students could also be provided with the option of choosing a specialization area in sustainable development designed within their program of study. In line with Kamp's presentation of the approaches of integrating sustainability, [18] also analysed models of sustainability integration and came up with three expensive approaches. These are: 'Re-built' or 'Re-desgn' approach, signifying wholly integration; 'Build-in' approach, which 
shows significant curricula changes; and 'Bolt-on' approach, implying cosmetic reform or just an awareness about SD. The 'Re-build' approach was described by [19] as inculcating the sustainability literacy in our graduates through understanding the immediate and long-term future of the ecology and socio-economy of societies and how they are impacted by human unsustainable actions; and through cultivating essential knowledge and skills that will make us adjust to a more sustainable way of doing things.

However, (20)\& (21) compiled the diverse approaches of sustainability into two (2) broad categories, namely, vertical and horizontal integration. Watson described vertical integration as a specific course on SD added to the curriculum; whereas horizontal integration involves integrating sustainability in many forms such as putting Sustainability Development issues as a topic in an existing course, fusing sustainability with an existing course so as to lace them together. Another dimension to the horizontal approaches can be designing a complete sustainability programme which can be chosen as a specialization option in a program of study. The vertical integration, Bolt-on integration and designing a new sustainability elementary course are in agreement in terms of its approach of integration in the thoughts of [21], [18], [17]. Similarly, the horizontal integration described by Watson conforms to 'Rebuilt' and 'Build-in' approaches; Transformation and Reformation approaches; and embedding the concept of SD into regular disciplinary courses and make it optional to graduate respectively.

Other scholars such as [22] have categorized the models of integration of sustainability course into two: Stand- alone and Integrated course model. The Stand-alone model is described as a course designed to provide a general knowledge and understanding about sustainability to students with no intention of making it part of their core courses. This model has an advantage of being offered as a general course in other faculties and programmes since sustainability ideas are not restricted to engineering courses alone. On the other hand, the integrated model requires a complete revision and reconstruction of entire engineering course curriculum to accommodate sustainability concepts in engineering application, evaluation and in synthesis level.

\section{CONCLUSION}

This study was conducted to find out the awareness about ESD among engineering community and also to study the approaches of integrating sustainability development in engineering education in Nigeria. Highlights of the study includes the need to improve the knowledge about sustainability development through sustainability education intervention and also the urgency of government to implement policies and strategies drafted on sustainable development in Nigeria. The various leading and predominant approaches on sustainability integration in higher education by different educators were also outlined so that higher institutions and faculties who are yet to embed sustainability in their curricula, but have the interest to do so, can have an idea of what approach might yield good results in their programmes.

\section{REFERENCES}

1. UNESCO. Education for Sustainability Lessons learnt from a decade of commitment Education for Sustainability From Rio to Johannesburg: Unesco-ONU. 2002.

2. Report N. Education in Nigeria. Afr Aff (Lond). 2017;XV(LIX):216-24.

3. Akeel U, Bell S, Mitchell J. Engineering and Sustainability Education in Nigeria. 2017;(September):18-21.

4. Akuru UB, Okoro OI. Renewable energy investment in Nigeria: A review of the renewable energy master plan. 2010 IEEE Int Energy Conf Exhib EnergyCon 2010. 2010;166-71.

5. Onuoha IJ, Kamarudin N, Aliagha GU, Okeahialam SA Atilola MI, Atamamen FO. Developing Policies and Programmes for Green Buildings. Int J Real Estate Stud. 2017;11(2):50-8.

6. Tunji-Olayeni PF, Mosaku TO, Oyeyipo OO, Afolabi AO. Sustainability strategies in the construction industry: Implications on Green Growth in Nigeria. IOP Conf Ser Earth Environ Sci. 2018;146(1).

7. Akeel U, Bell S, Mitchell JE. Assessing the sustainability literacy of the Nigerian engineering community. J Clean Prod. 2019;212:666-76.

8. Hoshii YK and N. Education for Sustainable Development at Universities in Japan. 2014.

9. Olagoke OA. Evaluating Building Sustainability Literacy Level in Nigerian Architectural Education. J Sustain Archit Civ Eng. 2018;21(4):23-8.

10. Von Blottnitz H, Case JM, Fraser DM. Sustainable development at the core of undergraduate engineering curriculum reform: A new introductory course in chemical engineering. J Clean Prod [Internet] 2015;106:300-7. Available from: http://dx.doi.org/10.1016/j.jclepro.2015.01.063

11. Tejedor G, Segalàs J, Rosas-Casals M Transdisciplinarity in higher education for sustainability: How discourses are approached in engineering education. J Clean Prod. 2018;175:29-37.

12. Gerston JRCODPLSAB\& L. A Case Study of a Coinstructed Multidisciplinary Senior Capstone Project in Sustainability. Adv Eng Educ. 2014;1-29.

13. McConville JR, Rauch S, Helgegren I, Kain JH. Using role-playing games to broaden engineering education. Int J Sustain High Educ. 2017;18(4):594-607.

14. Halbe J, Adamowski J, Pahl-Wostl C. The role of paradigms in engineering practice and education for sustainable development. J Clean Prod [Internet]. 2015;106:272-82. Available from: http://dx.doi.org/10.1016/j.jclepro.2015.01.093

15. Shing CKAI, Mohamad ZF, Aziz A, Raman A Integrating Components of Sustainability into Chemical Engineering Curricula *. Int J Eng Educ. 2016;32(6):2653-64.

16. Wojuola RN, Alant BP. Sustainable development and energy education in Nigeria. Renew Energy. 2019;136674.

17. Thürer M, Tomašević I, Stevenson M, Qu T, Huisingh D. A systematic review of the literature on integrating sustainability into engineering curricula. J Clean Prod. 2018;181:608-17.

18. Huntzinger DN, Hutchins MJ, Gierke JS, Sutherland JW Enabling sustainable thinking in undergraduate engineering education. Int $\mathrm{J}$ Eng Educ [Internet]. 2007;23(2):218-30. Available from: 
http://www.me.mtu.edu/ jwsuther/Publications/15_Hunt zinger_etal_2007_Enabling_Sus_Thinking_in_UG_Eng_ Ed.pdf

19. Martin S. Sustainable Development, Systems Thinking and Professional Practice. J Educ Sustain Dev. 2008;2(1):31-40.

20. Andamon UI-R and MM. Transformative learning: innovating sustainability education in built environment. Int J Sustain High Educ. 2004;

21. Watson MK, Lozano R, Noyes C, Rodgers M. Assessing curricula contribution to sustainability more holistically: Experiences from the integration of curricula assessment and students' perceptions at the Georgia Institute of Technology. J Clean Prod [Internet]. 2013;61:106-16. Available from: http://dx.doi.org/10.1016/j.jclepro.2013.09.010

22. Boks C, Diehl JC. Integration of sustainability in regular courses: experiences in industrial design engineering. J Clean Prod. 2006;14(9-11):932-9. 